\title{
Starch balance in perennial organs of Carya illinoinensis Koch in a production cycle
}

\author{
Edwin Amir Briceño Contreras ${ }^{1}$, Alejandro Moreno Reséndez ${ }^{2}$, Luis Manuel Valenzuela Núñez ${ }^{3}$, \\ Cristina García De la Peña ${ }^{4}$, Rafael Rodríguez-Martínez ${ }^{5}$, Juan Ramón Esparza Rivera ${ }^{6}$
}

\begin{abstract}
Pecan tree (Carya illinoinensis Koch) is a native specie in Northern Mexico and the Southeastern United States, both countries dominate the production of walnuts to worldwide. The objective was to determine starch balance in root and trunk monthly in two varieties (Western and Wichita), during a production cycle. Sampling was systematic. Results in root and stem showed differences in starch concentrations between varieties, Wichita presented higher concentrations than Western. Wichita variety, in both organs, showed better accumulation conditions of starch. In response to higher starch accumulation in this variety its due to biotic and abiotic requirements to develop up are less demanding than other varieties.
\end{abstract}

Index terms: carbohydrates; walnut; reserves; Western; Wichita.

\section{Balanço de amido em órgãos perenes de Carya illinoinensis Koch em um ciclo de produção}

Corresponding author: alejamorsa@hotmail.com

Received:March 07, 2021 Accepted: April 20, 2021

Copyright: All the contents of this journal, except where otherwise noted, is licensed under a Creative Commons Attribution License.

\begin{abstract}
Resumo - A noz-pecã (Carya illinoinensis Koch) é uma espécie nativa do norte do México e sudeste dos Estados Unidos da América, países que dominam a produção de nozes em todo o mundo. O objetivo foi determinar o balanço de amido na raiz e no tronco, mensalmente, em duas variedades (Western e Wichita), durante um ciclo de produção. A amostragem foi sistemática. Os resultados na raiz e no tronco mostraram diferença nas concentrações de amido entre as variedades. A variedade Wichita apresentou maior concentração de amido nos 12 meses em relação à Western. A variedade Wichita, em ambos os órgãos vegetativos analisados, apresentou melhores condições de acúmulo de amido. A resposta ao maior acúmulo de amido nesta variedade foi devido aos requisitos bióticos e abióticos para o desenvolvimento, sendo menos exigentes do que outras variedades.
\end{abstract}

Termos para indexação: carboidratos; noz-pecã; reservas; Western; Wichita. 


\section{Introduction}

The forest and fruit trees of perennial character are subject to changes that may present themselves in environmental conditions during their life cycle, which can occur between growing seasons over a year or as well in several years (VASCONCELOS-RIBEIRO et al., 2012). Nonstructural carbohydrate reserves play a principal role in the physiology and metabolism of perennial trees (FURZE et al., 2019).

Deciduous trees store carbohydrate reserves in the root and stem during periods when photosynthate production exceeds the demand for tree growth and metabolism (KOSLOWSKI et al., 1991).

Nonstructural carbohydrates are stored in living tissues in the forms of soluble sugars and starch that constitutes an energy source for the metabolism of trees when adverse conditions such as growth, respiration, osmoregulation and osmoprotection are present (HARTANN; TROMBORE, 2016; FURZE et al., 2019). Nonstructural carbohydrates are stored in organs on time scales that can range from minutes to several decades, allowing those trees to survive when respiration rates exceed photosynthesis rates in phenological events such as regrowth in deciduous species, as well as the influence of stress-inducing factors (FURZE et al., 2019).

Starch is the carbohydrate with the best indicator of carbohydrates status in trees (FORD; DEANS, 1977; ADAMS et al., 1986) and is the main form of carbohydrate storage in trees (TROMP, 1983; KOZLOWSKI, 1992). Starch concentrations present seasonal variations in deciduous trees and two maximum peaks are normally observed, one at the beginning and the other at the end of the dormant period (DICKSON, 1991; SAUTER; VAN CLEVE, 1991; KOZLOWSKI, 1992, JOHANSSON, 1993). The alternation during production in fruit trees is due to the depletion of starch reserves in the process fruit production and vegetative development, because the leaves cannot quickly replenish the reserves to supply the demands of a new flowering and development cycle of the fruits to the next year (DAVIE; STASSEN, 1997). This can cause after the harvest of a given year, the tree does not have enough reserves for a good production the next year (GAMBOA-PORRAS; MARÍN MÉNDEZ, 2012).

Given the economic importance of walnut cultivation in almond-producing in the region (Comarca Lagunera, Mexico), the objective was to analyze the starch balance on a monthly way in different vegetative organs of C. illinoinensis (Wangenh.) K. Koch, in two varieties (Western y Wichita), during a production cycle, as well as the contribution of starch to biomass at the tree level.

\section{Materials and Methods}

Study area. The study was carried out at the experimental orchard of the Universidad Autónoma Agraria Antonio Narro Unidad Laguna (25 33' 22.63"

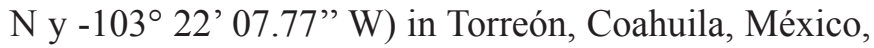
during the research period from July 2016 to June 2017. The region's climate is semi desert with an average annual rainfall of $230 \mathrm{~mm}$ (IMTA, 2005) with an elevation of 1,120 m (INEGI 2012).

Sampling. The sampling method applied in the walnut orchard during the research was a systematized type that consists of selecting trees using an established order. Sampling was carried out every month for a year in the same trees according to the methodology proposed by BARBAROUX, BRÉDA (2002) y VALENZUELANÚÑEZ et al. (2011). Four adult trees of the Western and Wichita varieties were selected. The orchard is under agronomic management with irrigation by flooding with well water, the age of the trees is 40 years, the planting density is 100 trees ha $^{-1}$ established in a real setting. The calendar includes eight irrigations with intervals of 12 to 47 days, depending on the phenological stage with a total irrigation sheet of $748 \mathrm{~mm}$ per year. The $\mathrm{pH}$ of the water is 8.2 and the electrical conductivity is 1,480 microohms $\mathrm{cm}^{-1}$. Two roots and two stem samples $(50 \mathrm{~g}$ each) were taken from each tree for each month. The stem samples were obtained in the form of chips with a Pressler ${ }^{\circledR}$ drill, at a height of $1.30 \mathrm{~m}$ and a conventional pick was used to extract the roots, making a small trench to locate the main root and extract the sample at a depth of $30 \mathrm{~cm}$. The samples were carefully cleaned removing soil debris and placed in perforated and labeled aluminum bags; they were frozen in liquid nitrogen to stop all biochemical processes in the tissues (VALENZUELA-NÚÑEZ et al., 2011).

Laboratory work. The samples were kept at a temperature of $-70^{\circ} \mathrm{C}$ in an ultra-freezer equipment for one week, and they were taken at a lyophilization process for seven days at a temperature of $-40^{\circ} \mathrm{C}$, to dehydrate the samples and avoid any enzymatic activity. The samples were ground in a knife mill to obtain a fine pulverization and $10 \mathrm{mg}$ of dry matter were weighed in using an analytical balance (VALENZUELA-NÚÑEZ et al., 2011).

Calibration curve. To determine the starch concentration in the different vegetative organs (roots and stems), rice starch was used as a standard, to later make a calibration curve for starch in different dilutions and established concentrations of $0.02,0.20,0.50,0.75,2,4$, 6,8 y $10 \mathrm{mg} \mathrm{mL}^{-1}$ of distilled water. Absorbance readings were registered using a spectrophotometer at $595 \mathrm{~nm}$. The results were processed with the Excel program, obtaining 
the following linear model: $y=0.3063 \mathrm{x}-0.0894$ with $\mathrm{r}^{2}=$ 0.9822 , where the independent variable (x) corresponds to starch concentrations and the dependent variable (y) to absorbance. Subsequently, a control sample was prepared with a concentration of $1 \mathrm{~mL}$ of distilled water solution and $50 \mu \mathrm{L}$ of iodine that allowed the comparative reading of starch in the different concentrations indicated previously with the support of a spectrophotometer at 595 nm (VALENZUELA-NÚÑEZ et al., 2011).

Determination of starch concentration. To determine the starch concentration was used the technique established by EBELL (1969) and HAISING; DICKSON (1982); $10 \mathrm{mg}$ of pulverized root and stem dry matter were weighed in microtubes on an analytical balance. $1 \mathrm{~mL}$ of distilled water was added to the microtubes and mixed in a vortex for 1 minute. Subsequently, the samples, for root and stem, were boiled in an electric plate, for 10 minutes at $100^{\circ} \mathrm{C}$ to gelatinize the starch. The samples were centrifuged at 2,500 rpm for 2 minutes, $300 \mu \mathrm{L}$ of the extract was taken and placed in new microtubes.
Then, $900 \mu \mathrm{L}$ of absolute ethyl alcohol was added; and centrifuged at 10,000 rpm for 5 minutes, to precipitate the starch in the microtube. The alcohol was carefully emptied from the microtube to leave only the precipitated starch and $1 \mathrm{~mL}$ of distilled water was added. The microtubes were placed in the vortex equipment for 3 minutes and $50 \mu \mathrm{L}$ of iodine solution $(0.01 \mathrm{~N} \mathrm{~L})$ was added to each of the microtubes. Finally, the absorbance was registered in a spectrophotometer at $595 \mathrm{~nm}$ using $1 \mathrm{~mL}$ of distilled water and $50 \mu \mathrm{L}$ of iodine as a control.

Statistical analysis. Factorial ANOVA was used, designed for systematized sampling, using the statistical program IBM-SSPS 20.0 (2018), with a significance of $P \leq 0.05$

Estimation of trees biomass. To calculate the volume of each tree organ, the density values of the walnut wood were used, adapting it to the allometric equations [1, 2 and 3]. Root biomass was determined according to the methodology of Drexhage et al. (1999) equation [1], and for the stem biomass the procedure of Brucciamacchie (1982) equations [2 and 3] was used:
Starch content in biomass. The determination of the starch content in the total biomass of the tree was obtained from the starch concentrations determined in each organ (mg of starch contained in one gram of dry matter) weighted to the biomass of the organs of the tree to total kilograms of starch expressed as percentage with respect to the total biomass of stems and roots separately and total biomass of the tree (VALENZUELA-NÚÑEZ et al., 2011).

\section{Results and Discussion}

Starch concentration in perennial organs. The results obtained in the root showed significant differences in the Wichita and Western varieties. Wichita had high concentrations of starch in the 12 months: January with the highest amount ( $\left.\bar{x}=65.50 \mathrm{mg} \mathrm{g}^{-1} \mathrm{DM}\right)$, and August in less quantity $\left(\bar{x}=32.20 \mathrm{mg} \mathrm{g}^{-1} \mathrm{DM}\right)$ (Table 1 y Figure 1). The value of $R^{2}(0.961)$, indicates that the variety and the month in which the collection was carried out have an effect on the starch concentration in the root. Individually, both the variety and the month affected the starch concentration in the root of the pecan tree $(\mathrm{F}=$ 573.136, g. $1 .=1,360 ; \mathrm{P} \leq 0.001 ; \mathrm{F}=707.263$ g. $1 .=11$, $360 ; \mathrm{P} \leq 0.001$; respectively). A significant interaction was observed between the two factors (variety-month) and the starch concentration in the $\operatorname{root}(\mathrm{F}=49.977, \mathrm{~g}$. 1 . $=11,360 ; \mathrm{P} \leq 0.001)$ (Table 2). The results in the walnut stem showed significant differences between the Wichita and Western varieties. The Wichita variety presented the highest concentrations of starch during the 12 months in the stem, being the month of October the one that presented the highest amount $\left(\bar{x}=61.62 \mathrm{mg} \mathrm{g}^{-1} \mathrm{DM}\right)$, and August the one that presented the least amount $(\bar{x}=41.17$ $\mathrm{mg} \mathrm{g}^{-1} \mathrm{DM}$ ) (Table 3 y Figure 2). The value of $\mathrm{R}^{2}(0.916)$, indicates the variety and the month in which the sampling was carried out explain the starch concentration in the stem. Individually, both the variety and the month affected the starch concentration in the stem of the pecan tree $(\mathrm{F}$ $=1687.048$, g. $1 .=1,360 ; \mathrm{P} \leq 0.001 ; \mathrm{F}=191$, g. $1 .=11$, $360 ; \mathrm{P} \leq 0.001)$. A significant interaction was observed between the two factors and the starch concentration in the stem $(\mathrm{F}=10.559, \mathrm{~g} .1 .=11,360 ; \mathrm{P} \leq 0.001)$ (Table 4).

Starch contribution to biomass at the tree level. The dry weight in kilograms of the total biomass of the four trees sampled for perennial organs by variety is presented in Table 5. 
Table 1. Descriptive statistics of starch concentration in root $\left(\mathrm{mg} \mathrm{g}^{-1} \mathrm{DM}\right)$ of pecan tree in a production cycle in two varieties (Western and Wichita).

\begin{tabular}{|c|c|c|c|c|}
\hline Variety & Month & Mean & Standar deviation & $\mathrm{n}$ \\
\hline \multirow{13}{*}{ Western } & July & 30.19 & 0.84 & 16 \\
\hline & August & 30.08 & 0.67 & 16 \\
\hline & September & 39.47 & 0.51 & 16 \\
\hline & October & 40.56 & 0.95 & 16 \\
\hline & November & 39.57 & 0.36 & 16 \\
\hline & December & 48.05 & 2.54 & 16 \\
\hline & January & 52.27 & 1.79 & 16 \\
\hline & February & 50.66 & 1.34 & 16 \\
\hline & March & 41.88 & 1.05 & 16 \\
\hline & April & 40.52 & 3.28 & 16 \\
\hline & May & 31.34 & 0.92 & 16 \\
\hline & June & 29.26 & 0.54 & 16 \\
\hline & Total & 39.49 & 7.87 & 192 \\
\hline \multirow[t]{13}{*}{ Wichita } & July & 32.86 & 0.81 & 16 \\
\hline & August & 32.20 & 0.55 & 16 \\
\hline & September & 42.57 & 1.71 & 16 \\
\hline & October & 41.49 & 1.10 & 16 \\
\hline & November & 43.44 & 1.78 & 16 \\
\hline & December & 64.26 & 3.95 & 16 \\
\hline & January & 65.50 & 5.27 & 16 \\
\hline & February & 61.74 & 4.22 & 16 \\
\hline & March & 42.11 & 0.92 & 16 \\
\hline & April & 41.15 & 1.61 & 16 \\
\hline & May & 34.20 & 1.11 & 16 \\
\hline & June & 34.79 & 2.74 & 16 \\
\hline & Total & 44.69 & 12.01 & 192 \\
\hline
\end{tabular}

$\mathrm{n}=$ number of samples

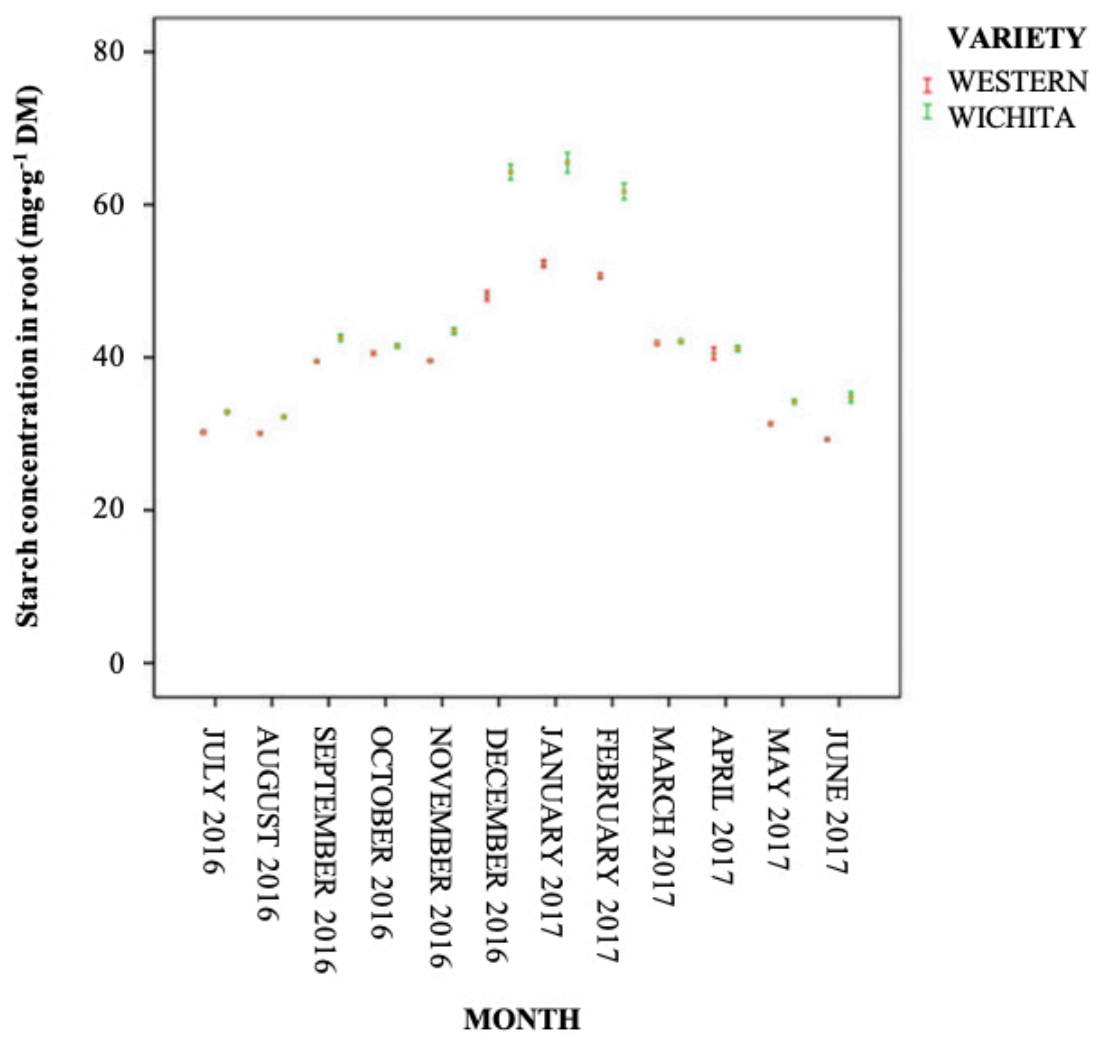

Figure 1. Comparison between the means of starch concentration in the root of pecan tree in a production cycle, in two varieties (Western and Wichita). The vertical bars show the typical error of the mean. 
Table 2. Factorial ANOVA of the effects in the interaction between factors: Variety-Month with respect to starch concentration in root.

\begin{tabular}{lllllc}
\hline \multicolumn{1}{c}{ Origin } & \multicolumn{1}{c}{ Sum of tables type III } & gl & Quadratic mean & \multicolumn{1}{c}{ F } & $P$ \\
\hline Corrected model & $40391.06^{\mathrm{a}}$ & 23 & 1756.13 & 387.07 & 0.000 \\
Intersection & 680414.31 & 1 & 680414.31 & 149973.23 & 0.000 \\
Variety & 2600.26 & 1 & 2600.26 & 573.13 & 0.000 \\
Month & 35296.63 & 11 & 3208.78 & 707.26 & 0.000 \\
Variety*Month & 2494.16 & 11 & 226.74 & 49.97 & 0.000 \\
Error & 1633.28 & 360 & 4.53 & & \\
Total & 722438.66 & 384 & & & \\
Total, corrected & 42024.34 & 383 & & & \\
\hline
\end{tabular}

squared $\mathrm{R}=0.961$ (squared-corrected $\mathrm{R}=0.959$ )

Table 3. Descriptive statistics of starch concentration in stem $\left(\mathrm{mg} \cdot \mathrm{g}^{-1} \mathrm{DM}\right)$ of pecan tree in a production cycle in two varieties (Western and Wichita).

\begin{tabular}{|c|c|c|c|c|}
\hline Variety & Month & Mean & Standar deviation & $\mathrm{n}$ \\
\hline \multirow[t]{13}{*}{ Western } & July & 37.75 & 0.91 & 16 \\
\hline & August & 34.08 & 1.24 & 16 \\
\hline & September & 48.27 & 1.59 & 16 \\
\hline & October & 50.51 & 2.06 & 16 \\
\hline & November & 51.21 & 3.06 & 16 \\
\hline & December & 39.63 & 0.43 & 16 \\
\hline & January & 39.88 & 3.19 & 16 \\
\hline & February & 38.49 & 0.76 & 16 \\
\hline & March & 36.91 & 0.49 & 16 \\
\hline & April & 37.92 & 0.64 & 16 \\
\hline & May & 35.49 & 0.69 & 16 \\
\hline & June & 33.42 & 2.15 & 16 \\
\hline & Total & 40.30 & 6.18 & 192 \\
\hline \multirow[t]{13}{*}{ Wichita } & July & 44.13 & 1.91 & 16 \\
\hline & August & 41.17 & 3.90 & 16 \\
\hline & September & 56.49 & 1.80 & 16 \\
\hline & October & 61.62 & 3.23 & 16 \\
\hline & November & 56.93 & 4.11 & 16 \\
\hline & December & 51.14 & 2.00 & 16 \\
\hline & January & 52.32 & 3.24 & 16 \\
\hline & February & 50.69 & 1.34 & 16 \\
\hline & March & 51.33 & 1.94 & 16 \\
\hline & April & 50.63 & 2.30 & 16 \\
\hline & May & 44.77 & 1.89 & 16 \\
\hline & June & 44.67 & 5.28 & 16 \\
\hline & Total & 50.49 & 6.46 & 192 \\
\hline
\end{tabular}

$\mathrm{n}=$ number of samples 


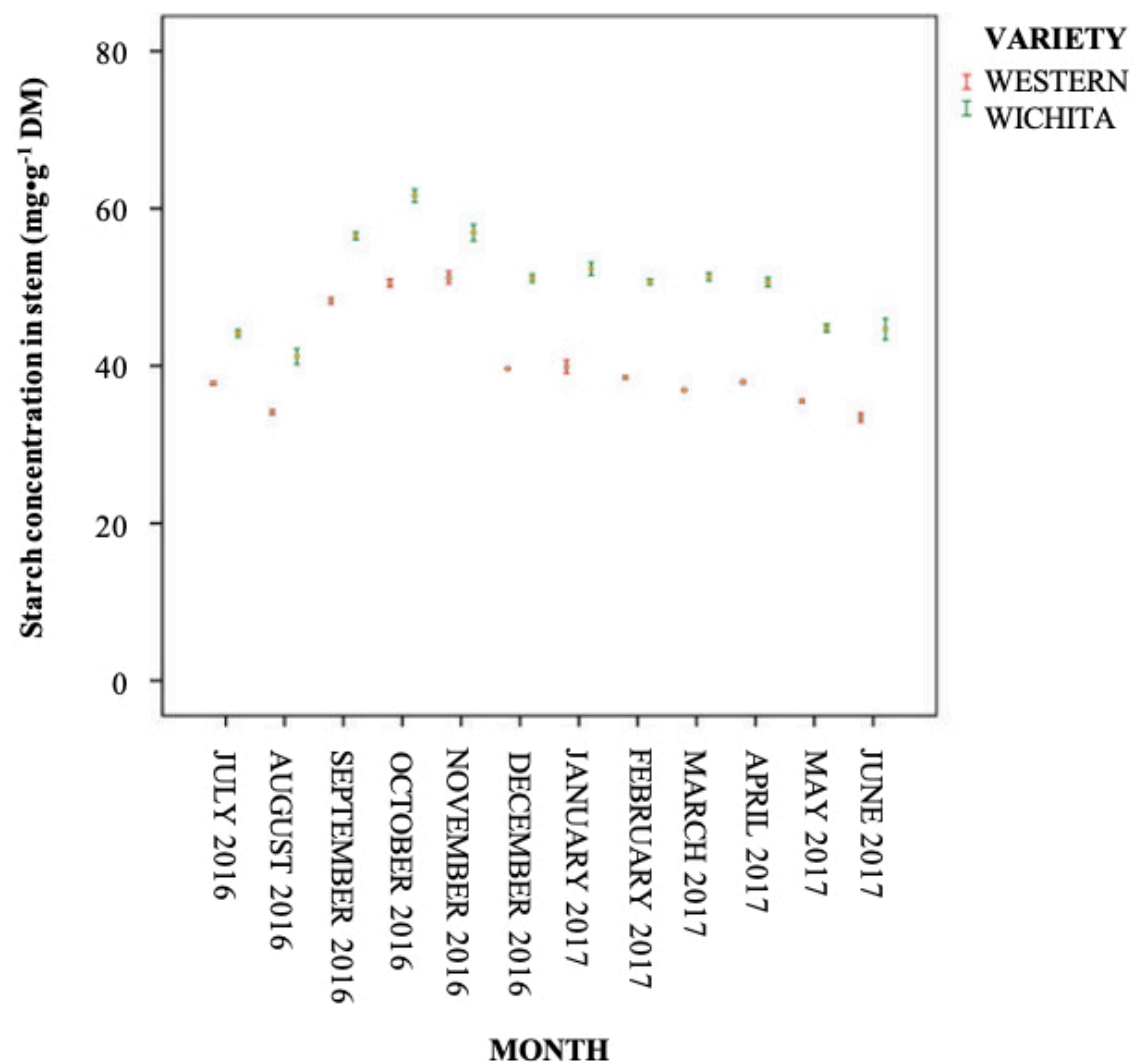

Figure 2. Comparison between the means of starch concentration in the stem of pecan tree in a production cycle, in two varieties (Western and Wichita). The vertical bars show the typical error of the mean.

Table 4. Factorial ANOVA of the effects in the interaction between factors: Variety-Month with respect to starch concentration in stem.

\begin{tabular}{cccccc}
\hline Origin & Sum of tables type III & gl & Quadratic mean & F & $P$ \\
\hline Corrected model & $23143.24^{\mathrm{a}}$ & 23 & 1006.22 & 170.16 & 0.000 \\
Intersection & 791411.89 & 1 & 791411.89 & 133834.70 & 0.000 \\
Variety & 9976.11 & 1 & 9976.11 & 1687.04 & 0.000 \\
Month & 12480.31 & 11 & 1134.57 & 191.86 & 0.000 \\
Variety*Month & 686.82 & 11 & 62.43 & 10.55 & 0.000 \\
Error & 2128.80 & 360 & 5.91 & & \\
Total & 816683.95 & 384 & & & \\
Total, corrected & 25272.05 & 383 & & & \\
\hline
\end{tabular}

Squared $\mathrm{R}=0.916$ (squared-corrected $\mathrm{R}=0.910$ )

Table 5. Total biomass (dry matter) of four trees, calculated using the models of Drexhage et al. (1999) and Brucciamacchie (1982) at the experimental site.

\begin{tabular}{|c|c|c|c|c|c|}
\hline & \multicolumn{5}{|c|}{ Total biomass in dry weight $(\mathrm{kg})$} \\
\hline \multirow{4}{*}{ Western } & & Tree 1 & Tree 2 & Tree 3 & Tree 4 \\
\hline & Stem biomass $(\mathrm{kg})$ & 281.56 & 234.39 & 521.31 & 425.61 \\
\hline & Root biomass (kg) & 107.14 & 85.99 & 224.73 & 176.03 \\
\hline & Total biomass of perennial organs $(\mathrm{kg})$ & 388.70 & 320.38 & 746.04 & 601.64 \\
\hline \multirow{4}{*}{ Wichita } & & Tree 1 & Tree 2 & Tree 3 & Tree 4 \\
\hline & Stem biomass (kg) & 216.22 & 309.29 & 309.29 & 270.07 \\
\hline & Root biomass (kg) & 78.07 & 119.92 & 119.92 & 101.91 \\
\hline & Total biomass of perennial organs $(\mathrm{kg})$ & 294.29 & 429.21 & 429.21 & 371.98 \\
\hline
\end{tabular}


The contribution of total starch in walnut tree represents 2.96 to $4.72 \%$ in the Western variety and 3.40 to $5.64 \%$ in the Wichita variety with respect to the total biomass of the tree.

The contribution of total starch in each vegetative organ of walnut tree represents in the root in the Western variety 2.90 to $5.29 \%$ and in the Wichita variety 3.13 to $7.13 \%$, in the case of the stem represents in the Western variety 3.18 to $5.39 \%$ and in the Wichita variety 3.72 to $5.64 \%$ with respect to the total biomass of the tree.

According to KOZLOWSKI et al. (1991), PIISPANEN Y SARANPÄÄ (2001), BARBAROUX et al. (2003), HOCH et al. (2003), GAMBOA-PORRAS; MARÍN-MÉNDEZ (2012); in woody trees, the roots are the organ where it accumulates the greatest amount of reserve carbohydrates, in the period prior to flowering, which means, these carbohydrates are mobilized for the development of new tissues. The results in this study showed that the root, of woody trees, is the vegetative organ where it accumulates the greatest amount of starch between varieties, and studied organs, prior to flowering, with Wichita being the best variety for both cases $(\bar{x}=$ $65.50 \mathrm{mg} \mathrm{g}^{-1} \mathrm{DM}$ in January, $\bar{x}=64.26 \mathrm{mg} \mathrm{g}^{-1} \mathrm{DM} \mathrm{In}$ December, and, $\bar{x}=61.74 \mathrm{mg} \mathrm{g}^{-1} \mathrm{DM}$ in February) during the dormancy stage, followed by the stem $(\bar{x}=61.62 \mathrm{mg}$ $\mathrm{g}^{-1} \mathrm{DM}$ in October, $\bar{x}=56.93 \mathrm{mg} \mathrm{g}^{-1} \mathrm{DM}$ in November, and, $\bar{x}=56.49 \mathrm{mg} \mathrm{g}^{-1} \mathrm{DM}$ in September,) during the production stage.

Regarding the phenological stage of dormancy, according to MARTÍNEZ-TRINIDAD et al. (2013) and Valenzuela-NÚÑEZ et al. (2011) during this stage, the roots and stems of deciduous trees reach the maximum value of reserve storage, being the root that presents the greatest accumulation, which coincides with the results reported by NAVARRO-CERRILLO; CALVO (2003); SANZ-PÉREZ et al. (2004); VALENZUELA-NÚÑEZ et al. (2011); GAMBOA-PORRAS; MARÍN-MÉNDEZ (2012) and KOZLOWSKI (1992) they refer that it is in the root where it accumulates the greatest amount of reserve carbohydrates in the period prior to vegetative growth. VALENZUELA-NÚÑEZ et al. (2011) reports a significantly higher starch concentration in the root with respect to the rest of the organs in deciduous trees in the dormancy stage. The results obtained in the present study coincide with the above, since the root reached the maximum storage value of reserves (starch), with Wichita being the best variety $\left(\bar{x}=65.50 \mathrm{mg} \mathrm{g}^{-1} \mathrm{DM}\right.$ in January, $\bar{x}=64.26 \mathrm{mg} \mathrm{g}^{-1} \mathrm{DM}$ in December, and, $\bar{x}=61.74 \mathrm{mg} \mathrm{g}^{-1}$ MS in February).

In the case of the stem; the differences between varieties showed that the Wichita variety, in the production stage (months from September to November, figure 2), presented a higher starch concentration, with respect to the dormancy stage (months from December to February, figure 2), which could be the result of the carbon contribution assimilated by the mature leaves during the production stage, and which also makes evident the demand for starch due to the diametrical growth of the stem (LACHAUD; BONNEMAIN, 1981); this behavior was presented inversely with respect to the starch concentration in the root, since in the production stage it decreased, increasing in the dormancy stage. This may also indicate that stem growth takes place during the production stage, while root growth takes place in the dormancy stage, as reported by VALENZUELA-NÚÑEZ et al. (2011) and VALENZUELA-NÚÑEZ et al. (2014). This pattern of growth and reactivation of tissues in different phenological stages is a very common behavior in porous wood species (ZIMMERMANN \& BROWN 1971) such as walnut tree (GONZÁLEZ-CERVANTES et al. 2014). Walnut tree, like other fruit trees, presents alternation in the productive cycle due to the decrease in starch reserves in the formation and metabolism of the fruit, this affects the reserves to meet the demands of a new cycle of flowering and fruit development for next year (DAVIE Y STASSEN, 1997).

During the dormancy stage, the trees remain defoliated and growth depends exclusively on the stored reserves (starch, sucrose), in latitudes such as the Comarca Lagunera, the dormancy stage is characterized by a decrease in the photoperiod and the environmental temperature, as a consequence the trees start a period of dormancy, which is preceded by periods with high temperatures, with the purpose for the tree to get new sprout without problems in spring (EL-ZEIN et al. 2011). The results in this study showed a higher starch concentration in the root with respect to the stem during dormancy, while an inverse effect was observed in the stem, this could be explained due to the fact that, in regions with clearly marked climatic seasons, in those the winter with temperatures close to freezing, at certain times of the day, even if they are few, can cause irreversible cell damage in species that are not adapted to these environment conditions and consequently adapted trees, among which the walnut tree stands out, it has developed mechanisms to avoid damage in tissue due to low temperatures. The trees of the Wichita variety keep their leaves for much longer in relation to other varieties, so the photosynthetic rate allows the synthesis of starch in greater quantity (ALMEIDA-GUILLEN, 2015).

The contribution of total starch in walnut tree represents in the Western variety 2.96 to $4.72 \%$ and in the Wichita variety 3.40 to $5.64 \%$ with respect to the total biomass of the tree according to BARBAROUX et al. (2003); DAMESIN; LELARGE (2003); HOCH et al. (2003) and VALENZUELA-NÚÑEZ et al. (2011). 


\section{Conclusions}

The Wichita variety, in both organs, presented better starch accumulation conditions due to its biotic and abiotic requirements to develop, which are less demanding than in other varieties grown in the area such as Choctaw and Cheyenne, which are more sensitive to extreme climatic factors. The root was the vegetative organ that presented higher starch concentration during the dormancy due to its growth in this stage, but the stem presents a major concentration in the production stage, although it is in this stage when there is growth in diameter, one characteristic of deciduous species. The present study was carried out in adult trees, so it would be advisable to make a comparison of carbohydrate reserves in young trees.

\section{Acknowledgments}

The authors express our gratitude to Dr. Ángel Lagarda Murrieta for the facilities to carry out this study in the experimental field at UAAAN-UL, and Dr. Guilherme Portes Silva for his support in the Portuguese translation.

\section{References}

ADAMS, M.B.; ALLEN, H.L.; DAVEY, C.B. Accumulation of starch in roots and foliage of loblolly pine (Pinus taeda L.): effects of season, site and fertilization. Tree Physiology, Oxford, v.2, n.1, p.3546, 1986.

\section{ALMEIDA-GUILLEN, J.A. Efecto de la longitud de brote sobre la viviparidad en la nuez pecanera (Carya illinoensis Koch) variedades Western Schley y Wichita. 2015. Tesis (Ingeniero Agrónomo en Horticultura) - Universidad Autónoma Agraria Antonio Narro, Torreón Coahuila, 2015. Disponível em: http://repositorio.uaaan. mx:8080/xmlui/bitstream/handle/123456789/7852/ JESUS \%20 ALEJANDRO \%20 ALMEID A \% 20 GUILLEN.pdf?sequence $=1 \&$ isAllowed $=\mathrm{y}$}

BARBAROUX, C.; BRÉDA, N. Contrasting distribution and seasonal dynamics of carbohydrate reserves in stem wood of adult ring-porous sessile oak and diffuseporous beech trees. Tree Physiology, Oxford, v.22, n.17, p.1201-1210, 2002.

BARBAROUX, C.; BRÉDA, N.; DUFRÊNE, E. Distribution of above-ground and below-ground carbohydrate reserves in adult trees of two contrasting broad-leaved species (Quercus petraea and Fagus sylvatica). New Phytologist, Lancaster, v.157, n.3, p.605-615, 2003.
BRUCCIAMACCHIE, M. Structure, croissance et biomasse des régénérations naturelles de chêne rouvre (Quercus petraea Liebl.). Champenoux: Institut National de la Recherche Agronomique, 1982. p.45. Disponível em: https://infodoc.agroparistech.fr/index. php?lvl=notice_display\&id=97157. Acesso em: 15 jan, 2020.

CHÁVEZ-RAMÍREZ, E.; GONZÁLEZ-BARRIOS, J.; VALENZUELA-NÚÑEZ, L.; POTISEK-TALAVERA, C.; GONZÁLEZ-CERVANTES, G. Morfología, índice y densidad estomática en plántulas de nogal pecanero cultivadas bajo tres niveles de radiación solar. Agrofaz, Venecia, v.9, n.3, p.85-90, 2009.

DAMESIN, C.; LELARGE, C. Carbon isotope composition of current-year shoots from Fagus sylvatica in relation to growth, respiration and use of reserves. Plant, Cell and Environment, Oxford, v.26, n.1, p.207219, 2003.

DAVIE, S.J.; STASSEN, P.J.C. Mango model: starch distri- bution of different tissues on "Sensation" mango trees of varying ages. Acta Horticulturae, The Hagye, v.455 n.1 p.143-150, 1997.

DICKSON, R.E. Assimilate distribution and storage. In: RAGHAVENDRA, A.S. (ed.). Physiology of trees. New York: John Wiley and Sons, 1991. p.51-85.

DONOVAN, G.H.; BUTRY, D.T.; MICHAEL, Y.L.; PRESTEMON, J.P.; LIEBHOLD, A.M.; GATZIOLIS, D.; MAO, M.Y. The relationship between trees and human health. Evidence from the spread of the EmeraldAsh Borer. American Journal of Preventive Medicine, Ann Arbor, v.44, n.1, p.139-145, 2013.

DONOVAN, G.H.; MICHAEL, Y.L.; BUTRY, D.T.; SULLIVAN, A.D.; CHASE, J.M. Urban trees and the risk of poor birth outcomes. Health \& Place, Edinburgh, v.17, n.1, p.390-393, 2011.

DONOVAN, G. H.; PRESTEMON, J. P. The effect of trees on crime in Portland, Oregon. Environment and Behavior, Washington, v.44, n.1, p.3-30, 2012.

DREXHAGE, M.; CHAUVIÈRE, M.; COLIN, F.; NIELSEN, C. N. Development of structural root architecture and allometry of Quercus petraea. Canadian Journal of Forest Research, Ottawa, Canada v.29, n.1, p.600-608, 1999. 
EBELL, L.F. Specifie total starch determinations in conifer tissues with glucose oxidase. Phytochemistry, Oxford, v.8, n.1, p.25-36, 1969.

EL-ZEIN，R.; MAILLARD，P.; BRÉDA，N.; MARCHAND, J.; MONTPIED, P.; GÉRANT, D. Seasonal changes of $\mathrm{C}$ and $\mathrm{N}$ non-structural compounds in the stem sapwood of adult sessile oak and beech trees. Tree Physiology, Oxford, v.31, n.1, p.843-854, 2011.

ESPINO-CASTILLO, D.; VALENZUELA-NÚÑEZ, L.; LEGARIA-SOLANO, J.; BRICEÑO-CONTRERAS, E.; ESPARZA-RIVERA, J.; RODRÍGUEZ-BAUTISTA, G.; GARCÍA-DE LA PEÑA, C. Evidencia de una proteína de reserva vegetativa de $20 \mathrm{kDa}$ en raíz de nogal (Carya illinoensis Koch) durante la etapa de letargo. Ecosistemas y Recursos Agropecuarios, Villahermosa, v.5, n.14, p.309-317, 2018.

FORD E.D.; DEANS J.D. Growth of a sitka spruce plantation: Spatial distribution and seasonal fluctuations of lengths, weights and carbohydrate concentrations of fine roots. Plant and Soil, Dordrecht, v.47, n.1, p.463-485, 1977.

FURZE, M.E.; HUGGETT, B.A.; AUBRECHT, D.M.; STOLZ, C.D.; CARBONE M.S.; RICHARDSON, A.D. Whole $\square$ tree nonstructural carbohydrate storage and seasonal dynamics in five temperate species. New Phytologist, Lancaster, v.221, n.3, p.1466-1477, 2019.

GAMBOA-PORRAS, J.R.; MARÍN-MÉNDEZ, W.Fenología, producción y contenido de almidón en árboles de mango en Guanacaste, Costa Rica. Agronomía Mesoamericana, San Pedro de Montes de Oca, v.23, n.1, p.81-91, 2012.

GARCÍA-HERNÁNDEZ, J.; ORONA-CASTILLO, I.; GONZÁLEZ-CERVANTES, G.; VALDEZ-CEPEDA, R.; MURILLO-AMADOR, B.; TROYO-DIÉGUEZ, E.; FORTIS-HERNÁNDEZ, M. Interacciones nutrimentales y normas de diagnóstico de nutrimento compuesto en nogal pecanero (Carya illinoensis).Revista Chapingo Serie Horticultura, Texcoco, v.15, n.2, p.141-147, 2009.
GARDEA, A.; MARTÍNEZ-TÉLLEZ, M.; YAHIA, E. Pecan (Carya illinoiensis (Wangenh.) K.Koch). In: YAHIA, E.M. (ed.) Postharvest biology and technology of tropical and subtropical fruits. Sawston: Woodhead Publishing Limited, 2011. p.143-165.

GONZÁLEZ-CERVANTES, G.; GONZÁLEZBARRIOS，J.; POTISEK-TALAVERA，M.; VALENZUELA-NÚÑEZ, L.; LÓPEZ-SANTOS, A. Radial growth of pecan (Carya illinoinensis (Wangenh.) K.Koch) wood under different water depths. Revista Chapingo Serie Zonas Áridas, Bermejillo, v.13, n.1, p.9-13, 2014.

GRAGEDA-GRAGEDA, J.; RUIZ-CORRAL, J.A.; JIMÉNEZ-LAGUNES, A.; FU-CASTILLO, A.Climate change influence on the development of pests and diseases of crops in Sonora.Revista Mexicana de Ciencias Agrícolas, Ciudad de México, n.10, p.19131921, 2014. Volume especial

HAISSIG, B.; DICKSON, R. Glucose measurement errors in enzymatic starch hydrolysates at high enzymeglucose weight ratios. Physiologia Plantarum, Copenhagen, v.54, n.1, p.244-248, 1982.

HARTMANN, H.; TRUMBORE, S. Understanding the roles of nonstructural carbohydrates in forest trees - from what we can measure to what we want to know. New Phytologist, Lancaster, v.211, n.2, p.386-403, 2016.

HOCH, G.; RICHTER, A.; KÖRNER, C. Non-structural carbon compounds in temperate forest trees. Plant, Cell and Environment, Oxford, v.26, n.1, p.1067-1081, 2003.

IBM-SPSS. Software IBM SPSS Statistics Version 20. New York, 2018. (Free trial). Disponível em: https:// www.ibm.com/mx-es/analytics/spss-statistics-software. Acesso em: 9 jun. 2018.

IMTA - Instituto Mexicano de Tecnología del Agua. Software ERIC 2.0.2005: extractor rápido de información climatológica. Ciudad de México, 2005. 
INEGI - Instituto Nacional de Estadística, Geografía e Informática. Anuario estadístico del estado de Coahuila de Zaragoza. Aguascalientes, 2012. Disponível em: http://internet.contenidos.inegi.org.mx/ contenidos/Productos/prod_serv/contenidos/espanol/ bvinegi/productos/integracion/pais/anuario_multi/2012/ coah/702825046583.pdf. Acesso em: 23 mar. 2020.

JOHANSSON, T. Seasonal changes in contents of root starch and soluble carbohydrates in 4-6-year old Betula pubescens and Populus tremula. Scandinavian Journal of Forestry Research, Garpenberg, v.8., n.1, p.94-106, 1993.

KOZLOWSKI, T.T.; KRAMER, P.J.; PALLARDY, S.G; ROY, J. The physiological ecology of woody plants. 4.ed. Saint Louis,: Elsevier Science, 2014. p.678.

KOZLOWSKI, T.T. Carbohydrate sources and sinks in woody plants. The Botanical Review, New York, v.58, n.2, p.107-222, 1992.

KRAMER, P.J.; KOZLOWSKI, T.T. Physiology of woody plants. London: Academic Press, London, 1979. $811 \mathrm{p}$.

LACHAUD, S.; BONNEMAIN, J.L. Xylogenèse chez les dicotylédones arborescentes.I.Modalités de la remise en activité du cambium et de la xylogenèse chez les hêtres et les chênes âgés. Canadian Journal of Botany, Ottawa, v.59, n.1, p.1222-1230, 1981.

LUNA-ESQUIVEL, E.N.; OJEDA-BARRIOS, D.L.; GUERRERO-PRIETO, V.M.; RUÍZ-ANCHONDO, T.; MARTÍNEZ-TÉLLEZ, J.J. Polyamines as indicators of stress in plants. Revista Chapingo Serie Horticultura, Texcoco, v.20, n.3, p.283-296, 2014.

MARTÍNEZ-DÍAZ, G.; JIMÉNEZ-LEÓN, J. Composición florística en los huertos de nogal pecanero en México. Distrito Federal México: INIFAP, 2008. p.5-8. (Libro técnico, 8).

MARTÍNEZ-TRINIDAD, T.; PLASCENCIAESCALANTE, F.O.; ISLAS-RODRÍGUEZ, L. Relationship between carbohydrates and vitality in urban trees. Revista Chapingo Serie Ciencias Forestales y del Ambiente, Texcoco, v. 19, n.3, p.459-468, 2013.
MEDINA-MORALES, M.C.; CANO-RÍOS, P. Aspectos generales del nogal pecanero. In: SALINASGONZÁLEZ, H.; QUIROGA-GARZA, M.; TIJERINACHÁVEZ, A.; FIGUEROA-VIRAMONTES, U. (ed.). Tecnología de producción en Nogal Pecanero. Matamoros: INIFAP, 2002. p.1-14. (Libro técnico, 3).

MEXAL, J.H.; HERRERA, E. Servicios ambientales de árboles: énfasis en la industria del nogal pecanero. Tecnociencia Chihuahua, Chihuahua, v.8, n.1, p.39-45, 2014.

MUNCHARAZ-POU, M. Orígen y descripción botánica de la especie (Carya illinoensis Koch). In: MUNCHARAZ-POU, M. (ed.). El nogal: técnicas de producción de fruto y madera Madrid: Mundi-Prensa, 2012. p.15-27.

NAVARRO-CERRILLO, R.M.; CALVO, J. Efecto de la fertilización de crecimiento con $\mathrm{N}$ sobre la arquitectura y el contenido de almidón en la raíz de brinzales de Pinus halepensis Mill., Pinus pinaster Aiton y Pinus pinea L. Scientia Gerundensis, Córdoba, v.26, n.1, p.29-39, 2003.

ORONA-CASTILLO, I.; ESPINOZA-ARELLANO, J.; GONZÁLEZ-CERVANTES, G.; MURILLO-AMADOR, B.; GARCÍA-HERNÁNDEZ, J.; SANTAMARÍACÉSAR, J. Aspectos técnicos y socioeconómicos de la producción de nuez (Carya illinoensis Koch.) en la Comarca Lagunera, México. Agricultura Técnica en México, Distrito Federal, v.32, n.3, p.295-301, 2006.

ORONA-CASTILLO, I.; SANGERMAN-JARQUÍN, D.; FORTIS-HERNÁNDEZ, M.; VÁZQUEZVÁZQUEZ, C.; GALLEGOS-ROBLES, M. Production and marketing of pecan nuts (Carya illinoensis Koch) in northern Coahuila, Mexico. Revista Mexicana de Ciencias Agrícolas, Ciudad de México, v.4, n.3, p.461476, 2013.

ORTÍZ-SÁNCHEZ, I.A.; ÁLVAREZ-REYNA, V.D.P.; GONZÁLEZ-CERVANTES, G.; VALENZUELANÚÑEZ, L.M.; POTISEK-TALAVERA, M.C.; CHÁVEZ-SIMENTAL, J.A. Concentration of starch and soluble proteins in tubers of Caladium bicolor under different phenological stages. Revista Mexicana de Ciencias Agrícolas, Ciudad de Mexico, v.6, n.3, p.483-494, 2015. 
PIISPANEN, R.; SARANPÄÄ, P. Variation of nonstructural carbohydrates in silver birch (Betula pendula Roth) wood. Trees, Berlin, v.15, n.1, p.444-451, 2001.

PALLARDY, S.G. Carbohydrates. In: PALLARDY, S.G. (ed.). Physiology of woody plants. 3.ed. Burlington, Academic Press, 2008. p.199-215.

PILAT, M.A.; MCFARLAND, A.; SNELGROVE, A.; COLLINS, K.; WALICZEK, T.M.; ZAJICEK, J. The effect of tree cover and vegetation on incidence of childhood asthma in metropolitan statistical areas of Texas. HortTechnology, Alexandria, v.22, n.5, p.631637, 2012.

POLETTO, T.; MUNIZ, M.F.B.; POLETTO, I.; STEFENON, V.M.; MACIEL, C.G.; RABUSQUE, J.E. Dormancy overcome and seedling quality of pecan in nursery. Ciência Rural, Santa Maria, v.46, n.11, p.1980-1985, 2016.

POTISEK-TALAVERA, M.C.; GONZÁLEZCERVANTES, G.; VALENZUELA-NÚÑEZ, L.; GONZÁLEZ-BARRIOS, J.L.; VELÁSQUEZ-VALLE, M. Respuesta del desarrollo y calidad de plantas de nogal pecanero a la fertilización nitrogenada bajo condiciones de invernadero. Agrofaz, Venecia, v.10, n.3, p.191-197, 2010

SANZ-PÉREZ, V.; CASTRO-DIEZ, P.; VALLADARES, F. Efectos de la disponibilidad de agua y nutrientes en el patrón de acumulación de carbohidratos en plántulas de tres especies de Quercus. Cuadernos de la Sociedad Española de Ciencias Forestales, Palencia, v.20, n.1, p.129-134, 2004.

SAUTER, J.J.; VAN CLEVE, B. Biochemical and ultrastructural results during starch-sugar-conversion in ray parenchyma cells of Populus during cold adaptation. Journal of Plant Physiology, Waterbury, v.139, n.1, p.19-26, 1991.

SAUTER, J.J.; WITT, W. Structure and function of rays: storage, mobilization, transport. $I n$ : ESCHRICH, W.; ZIEGLER, H. (ed.).Trees contribution to modern tree physiology. Leiden: Bachuys Publishers, 1997. p.177-195.
TROMP, J. Nutrient reserves in roots of fruit trees, in particular carbohydrates and nitrogen. Plant and Soil, Dordrecht, v.71, n.1, p.401-413, 1983.

USDA-NRCS - United States Department of Agriculture - Natural Resources Conservation Service. Pecan (Carya illinoinensis (Wangenh) K.Koch). 2016. Disponível em: http://plants.usda.gov/classification.html. Acesso em: 21 abr. 2017.

VALENTINI, G.; DAORDEN, M.E.; ARROYO, L. Características de variedades de nogal pecan en evaluación en la EEA San Pedro. San Pedro: Estación Experimental Agropecuaria, 2010. p.1-30.

VALENZUELA-NUÑEZ，L.M.; GÉRANT，D.; MAILLARD, P.; BRÉDA, N. Seasonal dynamics of total soluable proteins in adult trees of Quercus petraea (Matts.) Liebl.and Fagus sylvatica L. Revista Mexicana de Ciencias Forestales, Texcoco, v.1, n.1, p.75-83, 2010.

VALENZUELA-NUÑEZ, L.M.; GÉRANT, D.; MAILLARD, P.; BRÉDA, N.; GONZÁLEZCERVANTES, G.; SÁNCHEZ-COHEN, I. Evidence for a $26 \mathrm{kDA}$ vegetative storage protein in the stem sapwood of mature pedunculate oak. Interciencia, Caracas, v.36, n.2, p.142-147, 2011.

VALENZUELA-NÚÑEZ, L.M.; MAILLARD, P.; GONZÁLEZ-BARRIOS, J.L.; GONZÁLEZCERVANTES, G. Carbohydrate balance in different plant compartments of oak (Quercus petraea) and beech (Fagus sylvatica) subjected to defoliation and shade. Revista Chapingo Serie Zonas Áridas, Bermejillo, v.13, n.1, p.33-38, 2014.

VARGAS-PIEDRA, G.; ARREOLA-ÁVILA, J. Respuesta del nogal pecanero (Carya illinoensis $\mathrm{K}$ .Koch) a las aplicaciones foliares de nutrimentos. Revista Chapingo Serie Zonas Áridas, Bermejillo, v.7, n.1, p.7-14, 2008.

VASCONCELOS-RIBEIRO, R.; MACHADOCARUSO, E.; ESPINOZA-NÚÑEZ, E.; RAMOS, RÔMULO A.; MACHADO-FAVERO, D.SP. Moderate warm temperature improves shoot growth, affects carbohydrate status and stimulates photosynthesis of sweet orange plants. Brazilian Journal of Plant Physiology, Campinas, v.24, n.1, p.37-46, 2012. 
ZERMEÑO-GONZÁLEZ, A.; CRUZ-SANTES, C.; MUNGUÍA-LÓPEZ, J.; CATALÁN-VALENCIA, E.;

CAMPOS-MAGAÑA, G.; CORTÉS-BRACHO, J.

Efecto del sistema de riego y clima en la eficiencia del uso de agua de nogal pecanero. Terra Latinoamericana, Texcoco, v.32, n.1, p.23-33, 2014.
ZIMMERMANN, M.H.; BROWN, C.L. Trees: structure and function. New York: Springer-Verlag, 1971. 336 p. 